\title{
El gran libro del petricor
}

\section{verne.elpais.com/verne/2015/09/24/.../1443080571_244447.html}

Por Jaime Rubio Hancock

\section{GRANDES PREGUNTAS DE LA HUMANIDAD}

\section{7. ¿Por qué en películas y series nadie se despide cuando cuelga el teléfono?}

Porque es una pérdida de tiempo. Pongamos por ejemplo un capítulo de The Good Wife, donde los personajes pueden contestar al móvil cada cinco minutos. ¿Realmente necesitamos oír también "bueno, pues hasta luego, ya hablamos más tarde" al final de cada una de estas conversaciones? No. Puede que sea realista, pero por lo general es aburrido e innecesario. Además, los guionistas pueden aprovechar esos segundos para añadir más elementos a la trama. En este hilo de Reddit y en este otro de Quora comentan el tema y aportan más detalles.

\section{8. ¿Por qué bajamos el volumen de la radio cuando buscamos sitio para aparcar?}

La atención que podemos prestar es limitada, "un juego de suma cero", como explican en Sharpbrains. Para dedicar más atención a una actividad (buscar aparcamiento) debemos prestar atención de otra (escuchar la radio). En cambio, antes de buscar aparcamiento es muy probable que hayamos necesitado atender menos al camino y más a la música porque cada día hacemos la misma ruta al volver de la oficina. Otro ejemplo, sacado de Pensar rápido, pensar despacio: podemos caminar y hablar al mismo tiempo sin problemas, pero si caminamos y a la vez intentamos resolver un cálculo complicado, pasaremos a caminar más lentamente. Es decir, no somos multitarea.

\section{9. ¿Por qué no te puedes hacer cosquillas a ti mismo?}

Cuando movemos nuestras extremidades, "el cerebelo produce predicciones precisas de los movimientos de nuestro cuerpo", por lo que somos incapaces de sorprendernos a nosotros 
mismos y de hacernos cosquillas: sabemos dónde y cómo nos vamos a tocar, como explican en BBC.

20. Cada generación es más alta, pero ¿hay algún límite? ¿Acabaremos siendo monstruos de seis metros de alto? Por favor, que la respuesta a esta pregunta sea "sí".

Hemos crecido unos 10 centímetros en los últimos 100 años, más o menos y según recoge Martin Gent en 70 preguntas sobre el mundo que nos rodea y sus asombrosas respuestas, gracias sobre todo a "una alimentación más sana y una mejor asistencia médica". Pero este crecimiento está próximo a acabarse, según recoge este libro: “Los genes fijan a cada persona un límite máximo de aumento de estatura. En condiciones de vida óptimas este margen genético se puede utilizar entero, pero no superar". El cuerpo humano tiene sus límites: una altura excesiva puede provocar problemas cardiovasculares y en las articulaciones.

\section{1. ¿Se puede sudar dentro del agua?}

Cuando hacemos ejercicio físico, la temperatura del cuerpo comienza a subir y las glándulas sudoríparas se activan, como explican en Muy Interesante. Eso sí, si el agua está fría, sudaremos menos. 